\title{
Tukea opinnäyteprosessiin - mitä oppaat antavat?
}

Hakala, Juha T. (2007). Uusi graduopas. Gaudeamus Tuomi, Jouni (2007). Tutki ja lue. Johdatus tieteellisen tekstin ymmärtämiseen. Tammi.

Viitamäki, Leena \& Saari; Erkki (toim.) (2007). Polkuja soveltavaan yhteiskuntatieteelliseen tutkimukseen. Tammi.

Opinnäytteen ohjaukseen satsataan enemmän kuin koskaan. Ohjausta ja tohtorikoulutusta kehitetään ympäri maata. Kansainvälisille markkinoille tulvii opiskelutaidon ja väitöskirjan tekemisen oppaita. Suomenkielisilläkin markkinoilla julkaistaan jatkuvasti opinnäytteen ja tieteellisen kirjoittamisen oppaita sekä metodioppikirjoja. Tästä tarjonnasta luin Juha T. Hakalan "Uuden graduoppaan”, Leena Viinamäen ja Erkki Saaren "Polkuja yhteiskuntatieteelliseen tutkimukseen” sekä Jouni Tuomen "Tutki ja lue”.

Suomenkielisten kirjamarkkinoiden tilanteesta kertoo, että Hakalan oppaan lopussa listataan kokonaista 31 kappaletta suomalaisia opinnäyteoppaita. Käsillä olevien uutuuksien kirjoittajat eivät varsinaisesti käsittele kysymystä, miksi tarvittiin vielä yksi opas lisää. Sen sijaan he kertovat, että keskustelut opiskelijoiden kanssa ovat saaneet tarttumaan kynään.

Olemmeko akateemisina yhteisöinä edelleenkin osaamattomia tukemaan tieteellisen ajattelun kehittymistä? Gradu on pakko tehdä, jotta valmistuisi; pullonkaula on aina yhtä ahdas. Ongelma tuo hyödynnettävän markkinaraon, mutta onko oppaista apua? Onko oppailla tai hyvällä ohjauksellakaan mahdol- lisuuksia, jos opinnäytettä edeltävä koulutus ei tue tieteellisen ajattelun kehittymistä tai tutkivaa lukemista ja kirjoittamista?

\section{Noviisin aakkoset \\ tieteen kieleen}

Jouni Tuomen opas "Tutki ja lue", ei itse asiassa olekaan graduopas vaan opas tieteelliseen tekstiin perehtymiseen. Se pyrkii tukemaan juuri sitä opiskelun vaihetta, jossa opinnäytteen tekemiseen tarvittavat lukemisen taidot tulisi omaksua. Paljastuu, että Tuomen kirja on kirjoitettu silmällä pitäen niitä, jotka joutuvat lukemaan tutkimuksia päätöksenteon pohjaksi erityisesti terveydenhoidon konteksteissa. Kirjan esimerkit ovat lääke- ja hoitotieteen maailmasta, ja teksti peilaa tutkimusta ammattitiedon praktiseen maailmaan. Asetelma tuottaa kirjaan ratkaisuja, jotka voivat olla yliopisto-opetuksen näkökulmasta vaikeaselkoisia. Esimerkiksi metodologisia suuntauksia havainnollistetaan erittelemällä näkemyksiä terveyden edistämisestä, sairauksien etiologiasta ja hoidosta, sen sijaan että esitettäisiin tutkimusesimerkkejä.

Arkiajattelun ja tieteellisen ajattelun rajankäynti Tuomen oppaan alussa on puolestaan pedagogisesti toimiva idea.
Hyvä lähtökohta gradun teollekin olisi eritellä kriittisesti ensin omaa arkikäsitystä graduaiheeksi kaavaillusta ilmiöstä. Tuomen opas käsittelee selkein luokitteluin ja taulukoin tieteenfilosofisia koulukuntia, positivismin saadessa huolellisimman esittelyn.

Pidän kirjan jäsentelykehikkoa toimivana. Käyttäisin itse kirjaa nimenomaan metodikoulutuksessa taikka opinnäytteen teossa opeteltaessa lukemaan ja arvioimaan tutkimustekstejä ja harjoiteltaessa opponointia. Esimerkiksi luvun "Miten erotat tutkimuksen toisesta" jäsennys kysymyksineen on itsessään hyvä tukipuu erittelevän lukemisen harjoittelussa. Mielestäni tällaisten kirjojen anti on niiden vertailevassa ja jäsentelevässä perusrakenteessa. Se auttanee noviisia, joka opettelee esittämään tutkijan-kysymyksiä ensin omalle arkikokemukselleen, sitten tutkimuskirjallisuudelle ja tutkimusaineistolle sekä seminaarikaverien teksteille.

Oman havaintoni mukaan riskinä näiden rautalankamallien käytössä kuitenkin on, että yleisluontoisen oppaan sivuilta on helppo kopioida yksinkertaistuksia oman opinnäytteen metodiosaan.

\section{Vanhaa ja uuttakin metodeista}

Leena Viinamäen ja Erkki Saaren toimittaman metodikirjan kaltaisia suomenkielisiä metodikoos- 
teita on paljon. Täysin uutta sanottavaa ei varmasti ole helppo löytää, mutta teemavalinnat kertonevat jotain siitä, miten yhteiskuntatieteiden sovellusten kenttä kirjoittajien näkemyksen mukaan jäsentyy. Kirjoittajat ovat yhteiskuntatieteellisten aineiden ammatti- ja tiedekorkeakoulujen opettajia ja tutkijoita. Yhteiskuntatieteet ymmärretään hyvin laajasti inhimillistä toimintaa tutkiviksi tieteiksi.

Soveltavaan tutkimukseen opastava teos aloitetaan Anneli Pohjolan tekstillä tutkimuksen eettisyydestä. Eettisyys ymmärretään laajasti tutkimuksen tietoisena paikantumisena sekä tieteen kentälle että suhteessa ympäröivään yhteiskuntaan. Eettisyydellä tarkoitetaan myös perinteisemmin tutkimusta koskevien valintojen läpinäkyvyyttä. Tällaiset tekstit, joissa tutkimustoiminta avataan prosessina, ovat pedagogisesti ehkä opastekstien kaivatuinta materiaalia. Tieteen prosessiluonne, tutkijan valinnat sekä valinnoista seuraavat sitoumukset ovat juuri sitä hiljaisen tiedon aluetta, jota opiskelijoiden on vaikeinta tutkimuskirjallisuudesta seuloa esiin.

Erityisellä tavalla keskiöön eettiset kysymykset nousevat etnografisissa tutkimuksissa, joissa tarkastellaan ihmisten toimintaa arkisessa elinympäristössään ja tutkija käyttää omaa osallistumistaan ja persoonaansa tutkimusvälineinä. Vesa Puuronen esittää etnografiaa esittelevässä luvussaan, että etnografia on lähestymistapa, ei pelkkä metodi. Mikä on silloin etnografian tutkimuskohde tai suhde todellisuuteen? Mitä ilmiötä etnografia teoretisoi? Voisiko opinnäytteen rakentaa ilman mitään muuta teoreettista viitekehystä kuin etnografian? Kirjoittajan väittämä jää kesken, kun teksti joka seuraa, avaa lähinnä etnografian toimintatapoja ja tutkijan monia (sinänsä tärkeitä ja vaativia) eettisiä valintoja.

Napakkaa metodiaakkosten esittelyä ovat lomaketutkimusprosessia avaava Anja Aholan teksti sekä Leena Hietaniemen tilasto- ja rekisteritutkimuksen esittely. Selkiyttävä on myös Erkki Saaren toimintatutkimusta paaluttava luku. Tosin hieman puuduttavalta kirjoittamisen keinolta tuntuu suuren kokoavan taulukon ruutujen avaaminen yksi kerrallaan, aina samoihin lähteisiin viitaten.

Uudenlaisia tematisointeja teoksessa puolestaan edustaa esimerkiksi Leena Viinamäen triangulaation eli moninäkökulmaisuuden esittely. Triangulaatio on harvinainen valinta opinnäytteitä ajatellen, harvoinhan niissä lähdetään näin vaativiin asetelmiin. Lukiessani kuitenkin huomasin, että perinteisiä jaotteluja rikkovat tematisoinnit voivat olla pedagogisesti toimivia. Triangulaatiota on niin monenlaista, että käsitteitä avatessa kirjoittaja tulee selkiyttäneeksi tutkimuksen peruselementtejä; mitä valintoja tutkija joka tapauksessa tekee kaikessa tutkimuksessa.

Kirjasta löytyvät mainittujen lisäksi Jari Eskolan haastattelututkimusluku sekä Pirkko Vartiaisen monitahoarvioinnin esittely.

\section{Graduko kummajainen}

Juha T. Hakalan Uuden graduoppaan lukukokemus oli minulle ristiriitainen. Itse reagoin voimakkaasti kirjan tyyliin, vaikka samalla arvaan, että tyyli saattaa olla yksi teoksen suosion syistä. Jäin miettimään, onko hyvin lähelle tuleva lukijan puhuttelu ja ajatusten ennakointi ("mutta mutta, kivahdat nyt sinä", "minä jankutan koska olen virkamies”) pyrkimystä saada teksti dialogiseksi? Moniäänisyyden voisi kyllä luoda tekstiin muullakin tavoin. Tyylillä on ilmeisesti tavoiteltu graduntekijää ymmärtävää lähestyttävyyttä.

Yliopisto-opettajana minua kuitenkin häiritsee vielä enemmän tapa implikoida lukija henkilöksi, jolle gradu on kummajainen ja joka on ja tulee jäämäänkin tiedeyhteisön ulkopuolelle. Gradu (ja opettajat) tietenkin saattavat monillekin opiskelijoille näyttäytyä kummajaisina, mutta tarvitseeko outoutta pönkittää? Tutkimuksen tekeminen on yliopiston toinen perustehtävä. Siksi sekä gradun kokeminen triviaalina että sen myytinomainen mahdottomuus ovat yliopistopedagogiikan ja opetussuunnitelman vakava ongelma.

Entä jos graduopas avaisikin tieteen outouden sijasta sen järkevyyttä? Tutkijat kertoisivat, miksi tieteen tekeminen on innostavaa ja hyödyllistä? Miksi on tärkeätä (vaikkakin vaikeata) osata kysyä oikeita kysymyksiä, olla kriittinen ja peräänantamaton, lukea paljon? Opinnäytteen tekemisessä tarvittavat taidot ovat kuitenkin suurelta osin samoja, joita työelämässäkin tarvitaan: projektinhallintaa, ongelmien löytämistä, muokkaamista ja ratkaisemista, erilaisten viestinnän lajien hallintaa, palautteen antamista ja vastaanottamista, itsensä johtamista, joskus itsensä voittamista.

\section{Opinnäyte on ongelmanratkaisua}

Uskoakseni Hakalan oppaan menestyksen salaisuus kuiten- 
kin on, että ydinasia on jäsennetty hyvin. Opinnäytteen tekeminen jäsennetään valintoina ja ongelmanratkaisuna. Hakala tunnistaa osuvasti opinnäyteprosessin kaaren, kuljettaa lukijaa sen läpi ja tarjoaa realistista tukea. Viestinä on: käytä omia aivojasi, ajattele, lue, tee valintoja - ja kerro sitten valinnoistasi muille. Tämän perusviestin tunnistan kahdesta muustakin lukemastani oppaasta. Niissähän tutkimukseen opastaminen aloitetaan eettisten ja metodologisten sitoumusten tarkastelusta. Korostetaan että tutkimus on käytäntöjä, toimintaa ja valintoja, joista tulisi tulla tietoiseksi. Mielestäni tämä on pedagogisesti oikea suunta.

Hakalan teoksen eduksi on sanottava sekin, että se on todella luettava läpi, sieltä ei siis kovin helposti napsita sitaatteja metodi- tai luotettavuuspohdintoihin. Hakalan teoksessa jo sisällysluettelo on havainnollinen ja voi itsessään auttaa sekä opiskelijaa että opettajaa jäsentä- mään opinnäyteprosessia. Opiskelijan vinkkelistä tämä prosessi on syytä aloittaa varhaisella aikataulun suunnittelulla ja omalla tiukalla päätöksellä saattaa gradu valmiiksi. Sitten valmistellaan tutkimusaihe huolella, opetellaan lukemaan kirjallisuutta gradun tarpeisiin, aloitetaan kirjoittaminen mahdollisimman varhain - prosessikirjoittamisen opit kudotaan näin ohjeisiin luontevasti mukaan.

Gradun toteutusta kuvaava osa on kaavamaisempaa tutkimuksen toteutuksen esittelyä, mutta metodiosuudessaan tällainen yleisopas voikin olla vain viitteellinen. Ansiokasta on opastaa opiskelijaa itsearviointiin ja antaa siihen erilaisia välineitä. Kirja sisältaaä hyviä liitteitä, joiden avulla opiskelija voi pohtia omaa prosessiaan ja käydä läpi omaa tekstiään kriittisesti. Seminaarikaverit sen sijaan unohtuvat: ryhmässä työskentelyä, palautteen antamista ja vastaanottamisen taitoa ei juuri tuoda esiin.

\section{Oppaat tuovat hiljaista tietoa näkyväksi}

Yliopisto-opettaja voi käyttää omassa ohjaustyössään tällaisia oppaita hyödyksi monella tavalla. Ensinnäkin parhaimmillaan oppaissa ollaan herkkiä sille, mikä on vaikeata noviisitutkijalle ja millaisia kysymyksenasetteluja ja ihmettelyn lähtökohtia tutkimuksen maailmaan tutustuvalla voi olla. Tätä kysymystä ohjaajankin tulisi miettiä: miten tukisin oivallusta ja ongelmanratkaisuun suuntautuvaa ajattelua ja toimintaa?

Toiseksi oppaat auttavat hahmottamaan ohjausprosessin kulkua ja antavat runsain määrin ideoita siitä, miten opinnäyteprosessia ja sen eri vaiheita voisi lähestyä, mallintaa ja sanallistaa tai pilkkoa erilaisiksi osatehtäviksi. Opinnäytteen ohjaaminen on usein hiljaisen tiedon näkyväksi tekemistä. Siinä tavoitteessa oppaat ovat tärkeänä tukena.

Sanna Vehviläinen 